\title{
WestVirginiaUniversity
}

THE RESEARCH REPOSITORY @ WVU

Volume 45 | Issue 2

Article 17

February 1939

\section{Italy at the Paris Peace Conference}

Carl M. Frasure

West Virginia University

Follow this and additional works at: https://researchrepository.wvu.edu/wvlr

Part of the Comparative and Foreign Law Commons

\section{Recommended Citation}

Carl M. Frasure, Italy at the Paris Peace Conference, 45 W. Va. L. Rev. (1939).

Available at: https://researchrepository.wvu.edu/wvlr/vol45/iss2/17

This Book Review is brought to you for free and open access by the WVU College of Law at The Research Repository @ WVU. It has been accepted for inclusion in West Virginia Law Review by an authorized editor of The Research Repository @ WVU. For more information, please contact ian.harmon@mail.wvu.edu. 
the instructor would be at a loss to determine where to draw the line on duplication and where the "definitive and complete course" should begin and end.

Leo Caritn.

College of Law,

Morgantown, West Virginia.

Italy at the Paris Peace Conference. By René Albrecht Carrié. New York, N. Y. Columbia University Press, 1938. Pp. $\mathrm{xv}, 575$, maps.

This volume is one of a series, The Paris Pface Conference: History and Documenrs, that is being published by the Carnegie Endowment for International Peace. Although the great detail with which this volume is written makes it of primary interest to the scholar the work cannot be ignored by anyone who is attempting to understand the present confused relations of Italy, Germany, France, and Great Britain. Italian foreign policy for nearly twenty years has been largely determined by the failure of Italy to get from the Versailles Peace Conference and succeeding treaties what she felt rightly belonged to her both as a result of the provisions of the Treaty of London of 1915 and the fact that Italy came out of the war as one of the victorious states.

This book is divided into four parts. The first deals briefly with the war and Italy's entrance in 1915; the second covers the period of the Orlando-Sonnino Ministry from November 1918 to June 1919; the third treats the Nitti Ministry from June 1919 to June 1920; and the fourth gives us the final settlement, as it affected Italy, both on the continent and in Africa.

For the first time since the Versailles Conference Italy's case is here set forth to the world. There was nothing natural in Italy's alliance with Austria-Hungary except her desire to counteract French influence in northern Africa and she did not enter the war on the side of the central powers in 1914 primarily because she had little to gain even in victory. Strict neutrality was the best policy until the Allies made an attractive offer for her services, an offer which promised much more for Italy than the Central Powers had to give. Under these circumstances Italy, as an opportunist, joined the Allies in 1915 under the provisions of the "secret" Treaty of London. Before the end of the war Woodrow Wilson announced his Fourteen Points which were later accepted as a basis for peace and 
Italy quickly realized that the terms of the Treaty of London and the Fourteen Points could not be reconciled. About the same time Great Britain and France began to feel that Italy's price in 1915 had been too high and they saw in Wilson's program an outlet for: their own "rash" action in agreeing to Italy's demand at the time when they needed her services against Austria-Hungary. In consequence Italy soon found herself standing alone in her strictly national policy against the ideal of internationalism sponsored by Wilson, and backed by George and Clemenceau whenever Italy mentioned her claims under the Treaty of London. As the author so clearly brings out Italy was at once cast in the role of defender of the Old Order in Europe against the New Order as exemplified by the principle of self-determination of peoples. The spoils system in making peace had presumably given way to a more humanjtarian policy.

But Wilson with his idealism was only one obstacle in the way of Italy's claims, even though the most effective. The author is very critical of the policies of both Orlando and Sonnino, the leaders of the Italian delegation. According to him they weakened Italy's case through failure to insist more strongly upon the provisions of the London Treaty. In addition political differences and jealousies of members of the Italian Government further aggravated Italy's position at the Conference. The latter situation in part came about because of the failure of the Italian representatives at Versailles to overcome the opposition of Wilson to their claims, but it is difficult to see how any one could have done better than Orlando and Sonnino when we realize that Wilson had the support of both George and Clemenceau against Italy. To the author, Woodrow Wilson was the main cause of the embarrassing position that Italy found herself in at Versailles and Italy rejoiced at Wilson's defeat in the 1920 elections. In the Treaty of Rapallo, which followed almost immediately, Italy obtained through direct negotiations with Jugoslavia more than she was able to get from the Allies at Versailles. But it was too late for Italy to obtain what she considered a fair share of ex-enemy possessions in the Near East and in Africa.

If Italy represented the Old Order at the Versailles Conference her action was only in keeping with her agreement with Great Britain and France in 1915. Even though the price of Italy's assistance to the Allies may have been too high the Allies were willing to pay it when military necessity seemed to demand 
that they do so. Yet when circumstances permitted they were not unwilling to hide behind Woodrow Wilson's coat tails in denying that the Treaty of London was any longer applicable. This book will do much to help place Italian policy at the Versailles Conference in its true light. In doing so it will also shed some new light upon Allied policy and will aid in explaining the strained relations between Italy and Great Britain and France since that time. Even though the recent Munich Pact was not an Italian vietory in any sense Mussolini must have received some pleasure out. of the fact that Great Britain and France found themselves in an awkward position before Hitler and were compelled to accept a loser's terms.

An important feature of this volume is the more than two hundred pages of pertinent documents eovering the period from 1915 to 1919. There are also an adequate bibliography and an excellent index.

West Virginia University,

Carl m. Frasure.

Morgantown, West Virginia.

Trade Associations in Law and Business. By Benjamin S. Kirsh and Harold Roland Shapiro. New York. Central Book Company, 1938. Pp. 399.

In 1912, one year after the Supreme Court distilled the "rule of reason" out of the Sherman Anti-Trust Act, A. J. Eddy presented a forceful apologia for "cooperative competition," a term used to describe the trade association device which he sponsored. This year another apologia has appeared in print. Needless to say the sledding is much easier. The authors have behind them the fruition of a long struggle in which the courts have already carred out a comfortable niche for the trade association. The present work, however, is a theme on a variation from Eddy's. Whereas Eddy sought to provide an impetus for an incipient trade association movement, Messrs. Kirsch and Shapiro face a matured system in an attempt to demarcate what is economically desirable and legal from what is economically undesirable and illegal.

On the economic level, the tone of the book is Brandeisian. The authors sponsor an intelligent cooperation on the part of competitors, a cooperation which offers the advantages of large scale

1 FDD, ThE NeT Competition (1912). 